DOI: https://doi.org/10.47405/mjssh.v6i12.1187

\begin{tabular}{|c|c|}
\hline 4.581 & Malaysian Journal of Social Sciences and Humanities (MJSSH) \\
\hline $\begin{array}{l}\text { Malaysian Journa of } \\
\text { socal selenes and }\end{array}$ & Volume 6, Issue 12, December 2021 \\
\hline (MJ-SSH) & e-ISSN : 2504-8562 \\
\hline & $\begin{array}{l}\text { Journal home page: } \\
\text { www.msocialsciences.com }\end{array}$ \\
\hline
\end{tabular}

\title{
UPNM Way Forward: A Proposal of Cost Saving Strategy to Strengthen UPNM Financial Through Saving Plan Package
}

\author{
Mohd Fadhzil Bin Zainol ${ }^{1}$ \\ ${ }^{1}$ Faculty of Economics and Muamalat, Universiti Sains Islam Malaysia, Bandar Baru Nilai, \\ 78100 Nilai, Negeri Sembilan, Malaysia \\ Correspondence: Correspondence: Mohd Fadhzil Bin Zainol (fadhzil@upnm.edu.my)
}

\begin{abstract}
This study aims to determine and propose appropriate recommendation to the top management of university on how to generate income through saving plan that can be implement by Human Resource Department at UPNM to strengthen the financial issue. This proposal is proposed to assist management team on how to rationalize limited financial issues that can affect financial crisis faced by the university nowadays. At present, all public universities in Malaysia faced a critical challenge due to insufficient financial budget allocation, where the Government's financial allocation is increasingly bubbling. All Universities have been urged to generate their own internal income aside from budget allocation to ensure that the dependency on the Government can be reduce. Hence, some of these significant arrangement need to be carefully strategize and plan by the management of university to generate extra revenue as an effort to encounter financial issues faced by the university. From this case study, the finding can be used to identify and assist Top management of university to overcome issues on revenue generating to support financial operation cost at UPNM.
\end{abstract}

Keywords: cost effectiveness, financial issues, generate revenue, saving plan, UPNM

\section{Introduction}

Financial strength is one of the key elements to determine the success of an organization. A sufficient financial allocation is essential to the organization, not only drive the organization makes significant change but also ensure that the goals set forth by the university achieved its aim and objectives.

Based on the financial position in the annual financial report of 2017 it is clear that almost $45 \%$ of the financial allocation is budgeted for staff cost (salary) only. Due to these indicators, the management of university had instructed the Registrar's Department to conduct a benchmark study with other public universities to analyse the methodology and approach used by them in carrying out financial-saving plans on reducing financial allocations that focusing to emoluments and staff salaries. This study is crucial to ensure that financial management can be implement efficiently while ensuring the continuity capabilities of the university's financial.

Based on the studies and benchmarks that have been carried out to public universities in Malaysia, it shows that most of the public universities had manage and restructure their salary scheme. The scheme salary package has been carried out by their university's management as an effort to strengthen the university's financial return to be on a solid ground following the government's cuts. 
Doria Abdullah (2017) mentioned that before the budget cuts, public universities were in a comfortable financial situation, with no pressure to generate income through their core function. The reduced funding has necessitated swift changes across all functions. It started with short-term cost-cutting measures in administrative functions, travel reimbursement, and events management. Next, the institutions cut down on international faculty recruitment, academic staff mobility, and infrastructure development. Doria Abdullah (2017) also stated that due to the reduced fundings, universities have to find ways to generate their own income such as rentals and leasing of on-campus assets, increasing public consultancy services, and a push for commercialisation of $R \& D$ together with industrial sectors. Funding for Malaysian public universities is undergoing structural and strategic changes. The majority of funding for public universities previously came from Government and only approximately 10\% came from tuition fees (Ahmad, Soon, and Ting, 2015; Abdullah, 2017).

According to Doria Abdullah (2017), The Ministry of Higher Education is using budget cuts to push for two transformation agendas. The first agenda relates to governance. The Board of Directors (BOD), once a ceremonial and dormant structure in each public university, is now given the specific role of expediting decision making processes. The board also performs annual assessments to evaluate their effectiveness. The five research universities, namely Universiti Malaya, Universiti Kebangsaan Malaysia, Universiti Putra Malaysia, Universiti Sains Malaysia, and Universiti Teknologi Malaysia were the first group of universities that were granted financial autonomy, enabling them greater decision making power over student enrolments, academic management, human resources, and income generation. The second agenda relates to performance indicators and specific functions that support financial sustainability of the universities. The performance contracts of Vice Chancellors include targets on revenue generation, which affect the disbursement of future funding allocations, and overall performance evaluation. Other strategic functions include the Deputy Vice Chancellor for development, who works with the business development unit to unlock funding opportunities for the institution, and the Deputy Vice Chancellor for industry and community affairs, tasked to strategically engage with external players from the industry and from communities for academic and research collaborations.

Based on last meeting and discussion held by the Registrar's Department with the JPA on the issue of employment and occupation, the JPA officer has reprimanded and suggested UPNM to relook back at the salary package given to all the contract pensionable staff that UPNM hired. It not necessarily refers to the last drawn salary in service. Universities have a right to offer salaries based on the university's financial capabilities as contract staff recruitment is based on university requirement. Hence, several financial saving/income generate proposal have been proposed by the Registrar's Department to management of university. One of the proposal, is the rationalization of salary package given to pensionable academic staffs those aged above 60 years. Practice by other public universities is used as a benchmark for this study to shows that the implementation is standardized and applies to all public universities in Malaysia.

This case describes the saving plan implemented by Human Resource Department (HRD) in Universiti Pertahanan Nasional Malaysia (UPNM). This study was carried out in 2018 within the allotted threemonth period given by the coordinator of this Industry $\mathrm{PhD}$ programme. This case study shows how a manager at HRD rationalise limited financial issues faced by the university. At present, all public universities in Malaysia are facing a challenging time as the financial allocation is insufficient due to the Government's decision to cut financial allocation to public universities. All universities have been urged to generate their own internal income to make up the shortage from the Government allocation and also to ensure reduced dependency on the Government. Hence, some significant arrangements need to be carefully strategised and planned by the management of the university to generate extra revenue in the effort to achieve its financial objectives. The general objective of this case study is to examine the practices of emolument and compensation for UPNM staff. Performance management and, reward and recognition system must be aligned with UPNM's strategic plan to be a premier university in security and defence. For example, in order to ensure the best talents are recruited, UPNM needs to introduce new salary package within the budget allocation. There are many factors that influenced the financial position of the university including the budget cut by Government, huge allocation for emolument, and the presence of many contract staff in UPNM. 
Managing the financials is a very important aspect in the organisation. Without proper planning in managing the finance in the organisation, it can adversely affect the whole organisation. Many previous researches emphasised the function of good planning in the financials. Financial literature suggests that optimum application and commitment towards financial management practices result in an increased firm's performance. The financially well-managed firms are operationally efficient (Butt et al., 2010). Inefficiencies in financial management practices result in poor financial performance and eventually lead to failure of the organisation (Dennis, 2015).

Based on that the researcher strongly believed that corresponding with the previous literature review regarding the importance of financial management, the case study conducted by the researcher is closely related with regards to the problem of budget cut faced by UPNM. The Researcher used literature review as a guide and reference in developing and studying the problem in this case study. It is beneficial to the researcher as it provides more understanding on the problem in this case having past studies on finance as a guide.

Allah in Holy Quran says "Do not devour one another's property wrongfully, nor throw it before the judges in order to devour a portion of other's property sinfully and knowingly." (Al-Baqarah: 188) "Do not devour another's property wrongfully - unless it be by trade based on mutual consent." (Al-Nisa: 29).

\section{Materials And Methods}

This study used quantitative methodology as a tool. The quantitative methodology uses numerical analysis, statistics, and mathematical method to analyse both primary and secondary data. All data gathered helped determine the appropriate and suitable solution that can be used to solve the problem identified. In this case study, the research methodology used are as questionnaire (close-ended) and secondary data.

The data for this study was analysed using a statistical software known as SPSS. SPSS is a software product used for statistical analysis. SPSS is capable of handling huge amounts of data and can perform all of the analyses covered in the text and much more. SPSS was chosen because of its compatibility with most other software packages and its user-friendliness for data analysis (Field, 2009). Secondary data is also used and applied in this case study. Secondary data is used as supplementary to strengthen the case. Examples of secondary data are meeting minutes, annual reports, data of staff, etc. All the data is expected to assist the researcher and applied in this case.

\section{Data Gathered}

The data collected for this study was aimed at identifying the best implementation from the many recommendations on the implementation of financial savings by introducing a new salary package to UPNM's pensionable academic staff age above 60 years and also their recruitment as contract staff. Data used for this case study were gathered through a survey with the help of questionnaire distributed to Heads of Departments in UPNM. The questionnaires comprise of nine (9) questions and focused on several issues pertaining to financial issues, recommendations on income generation, etc. 40 respondents consisting UPNM's Heads of Department were chosen to answer the entire questions in the questionnaire. There are two reasons why they are selected by the researcher as respondents for this case study;

i. Consensus by Committee members of the case study.

ii. They are selected because of their posts which represent various departments in UPNM.

All the data collected were compiled into MS Excel data sheet to generate relevant statistical information for this case study. Data were also compiled from discussion and brainstorming sessions amongst Heads of Departments based on their expectation, feeling, and opinion on how to strengthen financial management in UPNM. Data were also compiled from Document Analysis/Document Review 
DOI: https://doi.org/10.47405/mjssh.v6i12.1187

as secondary sources to enhance the case study findings. Most of the secondary sources collected are from minute meeting (Meeting of Vice Chancellor, Management Meeting), mandate by Minister, benchmarking, journals, news, papers, and websites.

\section{Data Analysis}

A questionnaire was distributed by the Remuneration and Service Unit, HRD to Heads of Department to get their recommendations on how to help the university find a way to strengthen the financial standing. The recommendations are needed to determine the cost effectiveness in the university's expenditure for staff emolument at UPNM, that will help management to plan a saving approach. Several meetings and discussions were conducted to discuss and gather all the ideas given in order to ensure the execution of this recommendation will achieve the objective as targeted by top management.

\section{Finding and Discussion}

Results based on questionnaire responses are as follows:

Question 1:

Based on Table 1, most of the Heads of Department know about the issue of financial allocation cut by the ministry to all public universities including UPNM. They are aware of this problem through the financial management meeting chaired by the Vice-Chancellor. This issue is always raised and discussed especially amongst universities which are facing major challenges as a result of these financial allocation cut. This information is also highlighted in newspapers.

Table 1: Survey on Issue of Financial Allocation Cut by The Ministry

\begin{tabular}{clcccc}
\hline & Frequency & Percent & Valid Percent & $\begin{array}{c}\text { Cumulative } \\
\text { Percent }\end{array}$ \\
\hline Valid & NO & 10 & 25.0 & 25.0 & 25.0 \\
& YES & 30 & 75.0 & 75.0 & 100.0 \\
& Total & 40 & 100.0 & 100.0 & \\
\hline
\end{tabular}

Question 2:

From Table 2 shows 92.5\% (37 respondents) were aware that financial allocation cut by the ministry will indirectly affect UPNM. It shows that most of Heads of Department realised that the university needs to do something to overcome that problem. Only 7.5\% (3 respondents) said they were not aware of this issue.

Table 2: Survey on Staff Awareness on The Issue of Financial Allocation Cut by The Ministry

\begin{tabular}{llcccc}
\hline & Frequency & Percent & Valid Percent & $\begin{array}{c}\text { Cumulative } \\
\text { Percent }\end{array}$ \\
\hline Valid & NO & 3 & 7.5 & 7.5 & 7.5 \\
& YES & 37 & 92.5 & 92.5 & 100.0 \\
& Total & 40 & 100.0 & 100.0 & \\
\hline
\end{tabular}

Question 3:

Table 3 shows that $87.5 \%$ or 35 respondents agreed that saving plans or raising fund as control measures is crucial to be executed by UPNM in order to ensure the stability of the university's financial management. Only $12.5 \%$ (5 respondents) did not agree that saving plans or raising funds as control measures are crucial. 
DOI: https://doi.org/10.47405/mjssh.v6i12.1187

Table 3: Survey on The Opinion of Senior Officer on The Saving

Measures or Raising Funds

\begin{tabular}{llcccc}
\hline & Frequency & Percent & Valid Percent & $\begin{array}{c}\text { Cumulative } \\
\text { Percent }\end{array}$ \\
\hline Valid & NO & 5 & 12.5 & 12.5 & 12.5 \\
& YES & 35 & 87.5 & 87.5 & 100.0 \\
& Total & 40 & 100.0 & 100.0 & \\
\hline
\end{tabular}

Question 4:

Table 4 shows that most of the top management in UPNM (28 respondents from 40 respondents) believed that emoluments for contract staff contributed the highest financial cost allocation borne by university in the annual budget.

Table 4: Survey on The Cost Involved With High Financial Allocation Borne By University That Need To Be Saved

\begin{tabular}{llllll}
\hline & Frequency & Percent & Valid Percent & Cumulative Percent \\
\hline Valid & Medical Cost & 8 & 20.0 & 20.0 & 20.0 \\
& Overtime Claims & 3 & 7.5 & 7.5 & 27.5 \\
& Emoluments & 28 & 70.0 & 70.0 & 97.5 \\
& Medical Cost & 1 & 2.5 & 2.5 & 100.0 \\
& Total & 40 & 100.0 & 100.0 & \\
\hline
\end{tabular}

Table 5 shows the same proof that emolument for contract staff is one of the highest expenses in UPNM.

Table 5: Total Overall Allocation and Expenses for Contract Staff Emolument in UPNM

\begin{tabular}{ccc}
\hline Years & Total Allocation (RM) & Total Allocation Used (RM) \\
\hline 2014 & $8,785,907$ & $10,660,237$ \\
2015 & $16,030,907$ & $17,257,638$ \\
2016 & $17,820,928$ & $21,805,770$ \\
2017 & $16,572,904$ & $20,432,153$ \\
2018 & $17,728,000$ & $18,520,285$ \\
\hline
\end{tabular}

Question 5:

Table 6 shows that 21 respondents out of 40 respondents chose new package salary for retired academic staff aged above 60 years as the proposal that Registrar Department should prioritise to help the university ease the burden of increasing financial expenditures. 10 respondents agreed to the suggestion of terminating the contract for the provision of service remuneration of all contract staff to solve the problem. 7 respondents meanwhile opined that increasing student fees might help the university to solve the problem.

Table 6: Survey on Proposal Submitted By The Registrar Department That Help University Ease The Burden of Increasing Expenditures

\begin{tabular}{llcccc}
\hline & Frequency & Percent & Valid Percent & $\begin{array}{c}\text { Cumulative } \\
\text { Percent }\end{array}$ \\
\hline Valid & New package salary & 21 & 52.5 & 52.5 & 52.5 \\
& Increase student fees & 7 & 17.5 & 17.5 & 70.0 \\
& Terminate contract & 10 & 25.0 & 25.0 & 95.0 \\
\hline
\end{tabular}


DOI: https://doi.org/10.47405/mjssh.v6i12.1187

\begin{tabular}{lcccc}
\hline $\begin{array}{l}\text { Terminate and discontinue } \\
\text { all service contract }\end{array}$ & 2 & 5.0 & 5.0 & 100.0 \\
Total & 40 & 100.0 & 100.0 & \\
\hline
\end{tabular}

Based on the findings from this questionnaire, the Registrar Department conducted a benchmarking exercise with other public universities on the new salary package for their pensionable staff who were hired on a contract basis.

A series of discussion and meeting were conducted with the Deputy Vice Chancellor (Academic and International), Deans and Directors, Registrar, Bursar, and selected Professors to discuss and develop the criteria and policy on the new salary setting for the academic contract staff aged above 60 years to be implemented in UPNM. After a series of discussion and meeting, a proposal was brought to the Executive Council meeting (EXCO Meeting) which was supported and approved by the Board of Directors.

Table 7 shows the new salary setting according to the package and grade of positions:

Table 7: New Salary Package Based on Grade of Position

\begin{tabular}{clccc}
\hline No & Gred Position & $\begin{array}{c}\text { Package Salary } \\
(\mathbf{A})\end{array}$ & $\begin{array}{c}\text { Package } \\
\text { Salary (B) }\end{array}$ & $\begin{array}{c}\text { Package } \\
\text { Salary (C) }\end{array}$ \\
\hline 1 & JUSA A,B,C & RM8,000.00 & RM12,000.00 & RM15,000.00 \\
2 & DS53/54 & RM7,000.00 & RM8,000.00 & RM9,000.00 \\
3 & DU53/54 & & & \\
4 & DS51/52 & & RM7,000.00 & \\
5 & DU51 & & & \\
6 & DS45 & RM4,000.00 & \\
6 & DG44/48/52 & & RM5,000.00 & RM7,000.00 \\
8 & Fellow & & RM7,000.00 & \\
9 & Senior Fellow & RM9,000.00 & \\
10 & Fellow Principal & & RM15,000.00 & \\
\hline
\end{tabular}

Source: The salary setting according to the Package and Grade of Positions as agreed in the Board Committee Meetings No. 3/2018

*** Lecturers / fellows who achieve excellent academic / management / expertise criteria can be considered as Contract of Service (COS) according to the appropriate payroll matrix.

Question 6

Figure 1 shows $38 \%$ (15 respondents) chose infrastructures development such as lecture rooms and classrooms, as very significant to be allocated if the financial austerity measures proved successful. 33\% (13 respondents) meanwhile chose Hostel Development for students as the option for spending the saved money. 28\% (11 respondents) chose welfare development for staff and students as their option. Based on the Research Question 'What is the appropriate recommendation to help UPNM overcome the issue of budget cuts by the government?', the researcher and committee members proposed a new salary package for UPNM contract staff aged 60 years.

This new salary package was introduced to help UPNM in managing its finances effectively and efficiently and at the same time recruit and select the best staff who will contribute to the organisation. This new salary package was designed based on the findings from the questionnaire and secondary sources. Starting from 2019, the new salary package was implemented to 18 contract academic staff (Jan - June 2019) and as a result RM 388,624.32 had been saved through this implementation. Based on the data, there are 39 contract academic staff. 21 of them were given contract extension and the new salary package will be applied on them. Therefore, about RM 800,000 is expected to be saved by UPNM after the introduction of the new package. This money can be used for many things in UPNM. Table 8 shows the cost saving after the implementation of the new salary package. 
DOI: https://doi.org/10.47405/mjssh.v6i12.1187

Figure 1: Survey on Suggestion to The University Management on How the Money Should Be Used

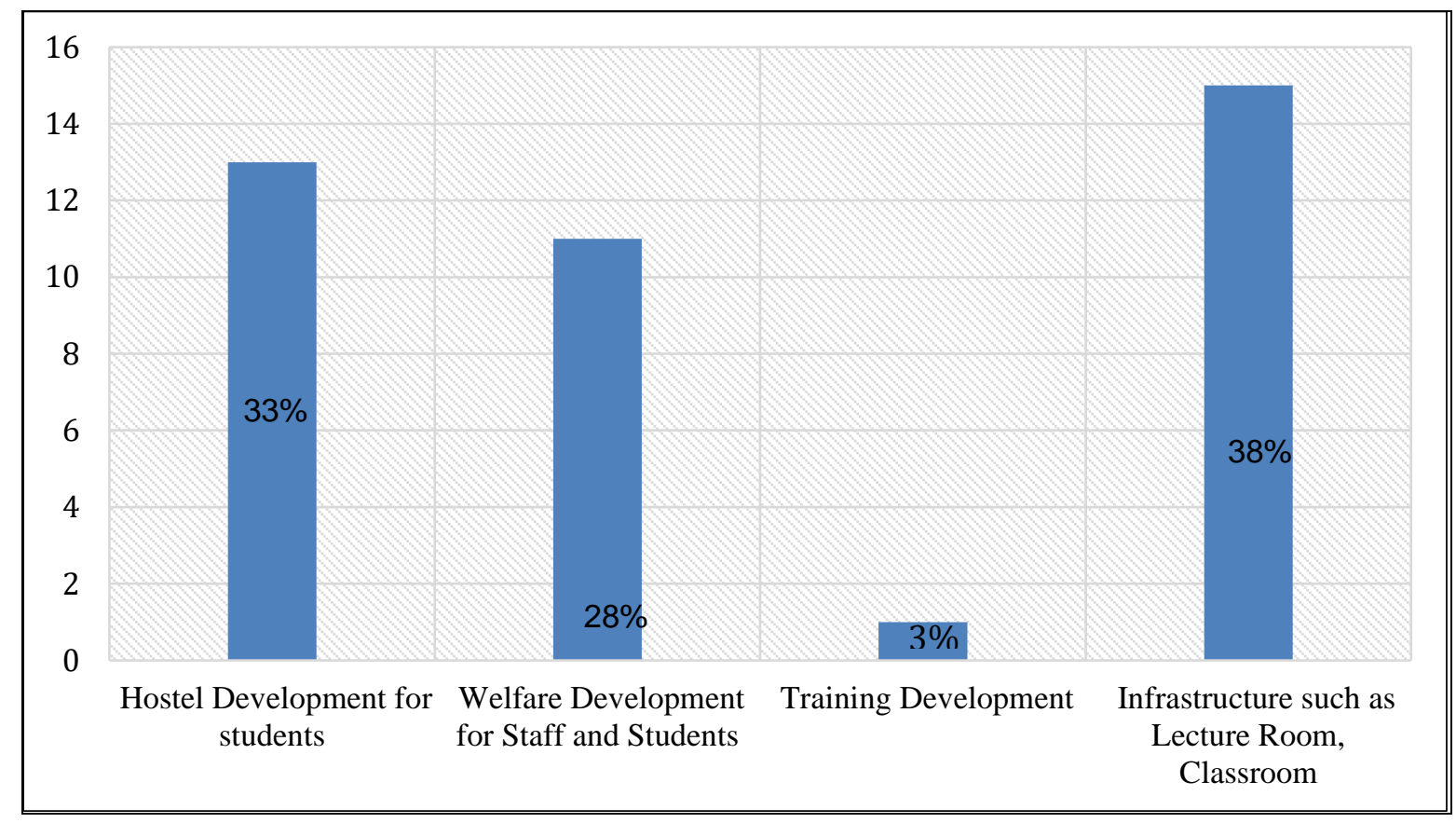

Table 8: Total Overall Saving (Jan-Jun 2019) For Retired Academic Contract Staff Above 60 years at UPNM

\begin{tabular}{lccc}
\hline FPJB & $\begin{array}{c}\text { UPNM Current } \\
\text { Expenditure/monthly } \\
(\mathbf{o s 2 9 0 0 0 )}\end{array}$ & $\begin{array}{c}\text { New UPNM } \\
\text { Expenditure/monthly } \\
(\mathbf{o s 2 9 0 0 0 )}\end{array}$ & $\begin{array}{c}\text { UPNM Cost } \\
\text { saving/monthly } \\
(\mathbf{o s 2 9 0 0 0 )}\end{array}$ \\
\hline FPPP & $130,510.36$ & $105,550.00$ & $24,960.36$ \\
FPKP & $137,710.00$ & $118,900.00$ & $18,810.00$ \\
FSTP & $20,615.00$ & $19,000.00$ & $1,615.00$ \\
FKJ & - & $12,000.00$ & $(12,000.00)$ \\
HADR & $6,000.00$ & $7,000.00$ & $(1,000.00)$ \\
TOTAL & $294,835.36$ & $262,450.00$ & $32,385.36$ \\
\hline
\end{tabular}

$\begin{array}{ll}\text { FPKP } & : 7 \\ \text { FPPP } & : 7 \\ \text { FKJ } & : 1 \\ \text { FSTP } & : 2 \\ \text { HADR } & : 1 \\ \text { Total } & : 18 \text { staff }\end{array}$

Total Savings: RM 32,385.36 x 12 months: RM 388,624.32 per year

\section{How to Value Perpetuity: Terminal Value?}

Cost Saving Annually from perpetuity $=$ interest rate $X$ present value $\mathrm{C}=\mathrm{r}$ X PV

$\mathrm{PV}$ of perpetuity $=\mathrm{C}=\underline{\text { cost saving annually }}$ $\mathrm{R}$ interest rate

Present Value of perpetuity $=\underline{\mathrm{C}}=842,400.00$

$\mathrm{R}=3 \%$

$=28,080,000.00$ 
Table 9: Five year projection on cost saving

\begin{tabular}{ccccc}
\hline Year 1 & Year 2 & Year 3 & Year 4 & Year 5 \\
\hline $\mathbf{2 8 , 0 8 0 , 0 0 0 . 0 0}$ & $\mathbf{2 8 , 0 8 0 , 0 0 0 . 0 0}$ & $\mathbf{2 8 , 0 8 0 , 0 0 0 . 0 0}$ & $\mathbf{2 8 , 0 8 0 , 0 0 0 . 0 0}$ & $\mathbf{2 8 , 0 8 0 , 0 0 0 . 0 0}$ \\
\hline
\end{tabular}

\section{5 years: $\underline{\text { RM 140,400,000.00 cost saving annually }}$}

\section{Recommendations For the Future}

This case study, both literature review and empirical findings clearly illustrated that emolument is one of the highest financial allocations that the university needs to put aside in its financial budget. This, however showed an unhealthy financial management for the university. Realising this shortcoming, the university's top management has instructed all the Heads of Departments to find ways and solutions to help the university raise fund through saving plans and measures. The scenario became worse when the Ministry announced budget cuts for all public universities starting from 2017. All public universities were requested to source for funds own their own and to $f$ increase their internal reserves without jeopardising the higher education system at the universities. Below are a few recommendations derived from this study:

Proposition 1: The management of the university should develop a fair salary package to hire contract academic staff. The university needs to benchmark with other universities to avoid any misunderstandings on the salary package offered.

Proposition 2: Based on the findings and feedback from the respondents, the new salary package should only apply to retired academic staff aged above 60 years, who are hired after their retirements. This is because these academic staffs are already earning their monthly pensions, and the new salary packages they will receive should depend on their contribution to UPNM.

Proposition 3: To ensure that the implementation of this new salary package meets the objectives of the university management and to avoid misunderstanding, it is recommended that a briefing session should be conducted to all stakeholders before the new salary package is introduced. The new salary package approved by the university should be well explained to all concerned parties so that all parties understand the rationale the implementation of this proposal thus getting the understanding and approval of the proposal.

Proposition 4: Savings after the implementation of the restructured salary package for lecturers above 60 years can be channeled to benefit lecturers such as providing seed grant, increasing allocation for seminars and conferences fees, etc.

\section{Potential Impact of Solution to The Organisation}

The proposed solutions forwarded to the top management have thus far been fully implemented. Overall, the value of the proposed solutions to the organisation are as table 10.

Table 10: Value for money (Saving Cost)

\begin{tabular}{llll}
\hline No & Process & Saving & Value (RM) \\
\hline 1. & $\begin{array}{l}\text { Financial savings because HR Department } \\
\text { only hires and select staff who meet the } \\
\text { KPIs. }\end{array}$ & $\begin{array}{l}\text { RM 1,800 x 12 month } \\
\text { x 41 staff }\end{array}$ & RM 842,400.00 (yearly) \\
\hline
\end{tabular}

The estimated figure derived from the introduction of new salary package for 39 contract academic staff's is about RM 842,400 hundred thousand per year. The outcome from this saving plan assisted the 
management of the university to utilise the saved amount for development projects benefiting UPNM's staff and students.

\section{Revenue From Cost Saving Channeled to Others Need}

Cost saving is very important for UPNM survival. Due to cost saving measures, the money acquired from cost saving plan, can be channeled to other priority needs such as hostel infrastructure, student's welfare, university development, etc.

\section{Lower Expenses}

The major benefit and impact of this solution perhaps is the cut down and reduction in the university's expenses. The university will be able to use the saved amount on its growth.

\section{Enhanced Efficiency}

Managing and planning appropriate and efficient organisational budget, help UPNM to ensure priority tasks are run and operate without hindrance within the allocated budget.

\section{Conclusion}

This case study shows that National Defence University of Malaysia (UPNM) needs this idea and recommendation in order to ensure the problem faced by top management on the Government budget cut can be resolved. The proposal on the saving plan helps top management save a lot of money and that money can be used on other projects especially to improve and enhance the welfare of students and staff. For example, from the savings realised, the top management can use the money for lecturers such as providing seed grants, increase allocation for seminars and conference fees, etc. With regards to the issue of budget cut by the Ministry, UPNM needs to be more dynamic, flexible, and more creative to find other sources of funds in order to ensure its financial stability of and at the same time ensuring the agenda on higher education is not affected.

As conclusion from this case study it is clear that National Defence University of Malaysia (UPNM) need this idea and recommendation in order to ensure problem faced by top management on budget allocation been cut from government can be resolve through this proposal by implement a New Salary Package for retired academic staff age above 60 years working at UPNM as contract. This proposal helps top management save a lots of money and its can be used and spend on others project especially to improve and enhance student and staffs' welfare and benefit. For example, from the saving the top management also can use the money for lecturer such as allocate seed grant, increase allocation for fees of seminars, conferences, etc. With regards to this issues on financial budget allocation been cutting by the Minister, UPNM need to be more dynamic, flexi and need be more creative to find other sources to raise fund in order to ensure stability of financial at UPNM and agenda on higher education at UPNM unaffected. The result of the introduction of new salary package is estimate about at RM 842,400 hundred thousand per year can be saved from 39 academic staff's contract. The outcome from this saving plan assist management of the university to utilize that amount of saving for beneficial development projects to UPNM staff and students need.

\section{References}

Amir Shaharuddin (2016). Shariah Issues in Islamic Banking and Facilities, Usim Press Universiti Sains Islam Malaysia

Auda, J. (2008). Maqasid Al-Sharial A Beginner Guide. The international Institute of Islamic Tought

Armstrong M. (2006), Strategic Human Resources Management, $3^{\text {rd }}$ edn, Landon: Kogan Page 
DOI: https://doi.org/10.47405/mjssh.v6i12.1187

Appari Gauri Sankar Rao (2017). Talent Management An going issue with Higher Educational Institutions in India. International Journal of Engineering Technology Science and Research, 4(7), 692-696.

Butt, Z. B., Hunjra, A.I. and Tehman, K.U. (2010). Financial management practices and their impact on organizational performance. World Applied Sciences Journal, 9(9), 997-1002.

Davis, Mark M., Nicholas J. Aquilano, \& Richard B. Chase (1999). Fundamentals of Operations Management. 3rd ed. Boston: Irwin McGraw-Hill.

DeCenzo, David A., Robbins, \& Stephen, P. (2009). Fundamentals of Human Resource Management10th edition. John Wiley \& Sons, Inc.

Doria Abdullah. (2017). Public universities and budget cuts in Malaysia. Journal International Higher Education, 15-16.

Field, A. (2009). Discovering Statistics Using SPSS. $3^{\text {rd }}$ Edition, Sage Publications Ltd., Landon.

Howard M.Schilit, Jeremy Perler, Yoni Engelhart (2018). Financial Shenanigans: How to Detect Accounting Gimmicks and Fraud in Financial Reports, $4^{\text {th }} e d$. McGraw Hill Education

John Jeston, Johan Nelis (2008). Management by Process

Khawaja \& Nadeem (2013): Training and Development Program and its Benefits to Employee and Organization: A Conceptual Study. European Journal of Business and Management, 5(2).

Kotler Keller (2015). Marketing Management. Harlov United Kingdom

Mary Buffet, David Clark (2008). Warren Buffet and the Interpretation of Financial Statements. New York, NY: Scribner

Walker, James. (2009). Human Resource Planning. New York: McGraw-Hill Book Co., P95.

Wheelen, T., \& Hunger, D. (2012). Strategic Management and Business Policy, (13 ${ }^{\text {th }}$ ed). U.S: Prentice Hall

Welch, J. (2009). Execution. In J. Welch, Execution. Busines Books.

Yin, R. K. (2014). Case Study Research: Design and Methods. SAGE Publications, Inc

Yusuf Ali (trans.) The Meaning of the Holy Qiran. Bretwood, Md Amana, 1999. 